\title{
PARAOXONASE ACTIVITY IN SERA FROM PIARACTUS MESOPOTAMICUS HOLMBERG (CHARACIDAE) AND HYPOSTOMUS PUNCTATUS VALENCIENNES (SILURIDAE)
}

\author{
Vera Lucia F. Cunha Bastos ${ }^{1}$ \\ Ana Rossini ${ }^{1}$ \\ Marcelo V. Alves ${ }^{1}$ \\ Paulo S. Ceccarelli ${ }^{2}$ \\ José A. Ferraz de Lima ${ }^{2}$ \\ Jayme Cunha Bastos ${ }^{1}$
}

\begin{abstract}
A paraoxonase activity present in serum of two Brazilian fish species was consistently assayed at $\mathrm{pH} 8.5$ using $7.5 \mathrm{mM}$ paraoxon final concentration. The paraoxonase activity was more activated by $0.5 \mathrm{M} \mathrm{NaCl}$ in serum of Piaractus mesopotamicus Holmberg, 1887 (pacu) than in serum of Hypostomus punctatus Valenciennes, 1840 (cascudo). Apparent values of $\mathrm{K}_{\mathrm{M}}$ were $3.3 \times 10^{-3} \mathrm{M}$ for cascudo and pacu paraoxonase activity in the presence of $0.5 \mathrm{M} \mathrm{NaCl}$. Apparent maximum velocity values calculated in the presence of $0.5 \mathrm{M} \mathrm{NaCl}$ were 6.1 and $6.5 \mathrm{nmo}$ le $/ \mathrm{min} / \mathrm{mL}$ of serum for cascudo and pacu, respectively. $\mathrm{V}_{\max } / \mathrm{K}_{\mathrm{M}}$ ratio values of determinations in the presence and absence of $0.5 \mathrm{M} \mathrm{NaCl}$ showed that $\mathrm{NaCl}$ had a more evident effect on increasing the affinity of serum paraoxonase for paraoxon in pacu serum. Young specimens of pacu showed a marked decreased paraoxonase serum activity when kept in tanks treated with $0.25 \mathrm{ppm}$ methyl-parathion.

KEY WORDS. Detoxication, fish, organophosphate, serum esterases
\end{abstract}

Studies on fish enzymes capable of catalyzing the metabolism of pesticides are important to elucidate the processes of intoxication and detoxication in fish exposed to pollutants. Knowledge coming out from such studies can supply the fundamentals to assess intoxication levels yet not macroscopically evident; what is of major utility to keep, during long periods, environmental pollution at compatible levels with life. Indeed, concerning sublethal intoxication of fish, it is noteworthy that pesticides have been used in fish-farming tanks in order to avoid proliferation of predatory insects and parasites which ordinarily attack fish (GRAVE et al. 1991a,b).

1) Departamento de Bioquímica, Instituto de Biologia Roberto Alcântara Gomes, Universidade Estadual do Rio de Janeiro. Avenida Prof. Manuel de Abreu 48, 20550-170 Rio de Janeiro, Rio de Janeiro, Brasil.

2) Centro Nacional de Pesquisas em Peixes Tropicais. Caixa Postal 64, 13630-970 Pirassununga, Säo Paulo, Brasil. 
Parathion (O,O-diethyl O-p-nitrophenyl phosphorothionate) is still largely used in Brazil to fight agricultural pests. Its original molecule is not toxic, but after undergoing metabolism it renders paraoxon (DIGGLE \& GAGE 1951; DUBOIS 1961; NEAL 1967), a phosphate ester (O,O-diethyl O-p-nitrophenyl phosphate), which well known toxic effects come from its ability to inhibit nerve acetylcholinesterase - AChE (BENKE et al. 1974; MAIN 1976). Inhibition of AChE by paraoxon results in accumulation of $\mathrm{ACh}$ in cholinergic synapses and neuromuscular plates, provoking a steady depolarization of the affected neurons. This might cause death due to respiratory paralysis (NATOFF 1971; MURPHY 1975; BRIMBLECOMBE 1977).

Many living animals are able to get rid of paraoxon through hydrolysis reactions which produce $p$-nitrophenol and diethylphosphoric acid (NEAL \& DUBOIS 1965; PLAYFER et al. 1976; Li et al. 1993, 1995). This hydrolysis can be specifically catalized by an enzyme named paraoxonase (ALDRIDGE 1953). Paraoxonase owes its name to the fact that it shows specificity to paraoxon, albeit being also able to hydrolyze other organophosphate pesticide analogs (REINER et al. 1993; WALKER 1993).

We were able to demonstrate that the liver of cascudo, Hypostomus punctatus Valenciennes, 1840, a bottom dwelling suckermouth catfish, is capable of biotransforming parathion into paraoxon (CUNHA BASTOS et al. 1992). We also showed that brain tissue of cascudo converts parathion into paraoxon (CUNHA BASTOS et al. 1988). Livers and brains of pacu, Piaractus mesopotamicus Holmberg, 1887, showed to be able to biotransform parathion into paraoxon, as well (data not published). It can be expected that at least a portion of the formed paraoxon in both tissues might be hydrolyzed. Different levels of nerve intoxication may become apparent depending on the promptness with which the in vivo formed paraoxon undergoes hydrolysis. In fact, some insects and birds are more sensitive to organophosphates insecticides because they lack the enzymes able to hydrolyze such compounds (BREALEY et al. 1980; WALKER \& MACKNESS 1987; ECOBICHON 1996).

Attempts to clarify whether serum paraoxonase levels of activity could be involved with nerve intoxication in fish are now in progress in our laboratory. So far no detailed description on paraoxonase determinations in fish serum has been available. Except by trout liver, it has been published that fish tissues showed no appreciable paraoxon hydrolyzing activity (CHEMNITIUS et al. 1983).

Kinetic properties of any enzyme can vary among species in such a way that in vitro determinations performed without validation of parameters like optima $\mathrm{pH}$, substrate concentration and temperature could be responsible for unreliable results. The results described here were obtained from experiments using specimens of $H$. punctatus and $P$. mesopotamicus. Detailed steps to characterize paraoxonase activity present in serum from both fish and the curves corresponding to the ideal parameters for the determination of this activity in vitro are presented. Paraoxonase activity assays using sera of young pacus raised in tanks pretreated with methyl-parathion were also carried as an attempt to understand whether this serum pesticide hydrolytic activity could be related to any possible level of intoxication in fish. 


\section{MATERIAL AND METHODS}

\section{Fish}

Specimens of H. punctatus (cascudo) were obtained from the Aquaculture Department of the Rio de Janeiro Federal Rural University (UFRRJ). Sexually mature males and females of cascudo were used. Fish weighed approximately 250 $\mathrm{g}$ and measured between 28 and $33 \mathrm{~cm}$. Specimens of $P$. mesopotamicus (pacu) were kindly donated by the National Centre for Research on Tropical Fish (CEPTA) of the Brazilian Environment and Renewable Natural Resourses Institute (IBAMA). Pacus measured around $23 \mathrm{~cm}$ and weighed approximately $150 \mathrm{~g}$. After arriving in the laboratory the animals were kept in $500 \mathrm{~L}$ aerated tanks equiped with biologic filter containing dechlorinated water. Fish were aclimated for at least 10 days before being used. Eggs of $P$. mesopotamicus were artificially fertilized in November 1995 at CEPTA facilities. Post-larvae pacu specimens were divided into two tanks (350 $\mathrm{m}^{2}, 1.2 \mathrm{~m}$ deep). After two days one tank received methyl-parathion to $0.25 \mathrm{ppm}$. Three months later fish from both tanks $(10-12 \mathrm{~cm}$, weighing $24-28 \mathrm{~g})$ were collected to have their serum paraoxon esterase activities compared.

\section{Sera}

Cascudo blood was obtained from cardiac puncture. Pacu blood was from dorsal aorta puncture, injecting the needle beneath the lateral line into points located between the tail and the middle of the fish's body. Tubes with blood stayed at $20^{\circ} \mathrm{C}$ until completely clotted. Then, they were kept in a refrigerator for $20 \mathrm{~min}$. After centrifugation at 3,000 rpm the serum was collected from each tube with a long needle. The sera used for the assays were up to 5 days old (kept under refrigeration).

\section{Reagents}

Trichloroacetic acid (TCA), 2-amino-2-(hydroxymethyl-1,3-propanediol (Trizma $\left.{ }^{\circledR}\right)$, hydrochloric acid $(\mathrm{HCl})$, paraoxon $(\mathrm{O}, \mathrm{O}$-diethyl $\mathrm{O}$-p-nitrophenyl phosphate) and dimethyl sulfoxide (DMSO) were purchased from Sigma Chemical Company, St. Louis, MO, U.S.A. Hexane specific for pesticide analysis was purchased from Grupo Química Industrial Ltda., Rio de Janeiro, Brazil. Methyl-parathion was donated by Centro de Estudos da Saúde do Trabalhador e Ecologia Humana (CESTEH) of Oswaldo Cruz Institute, Rio de Janeiro. All other chemicals were of analytical grade.

\section{Paraoxon repurification}

Paraoxon bought from Sigma had an amount of p-nitrophenol (p-NP) contamination which was extracted using hexane. A small volume of paraoxon was

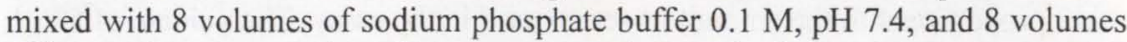
of hexane in an assay tube. This content was vigorously shaken to ensure paraoxon solubilization, changing the hexane as repeatedly as needed. Each time, after phase separation, the superior layer was transferred to a brownish-glass flask and nitrogen was then bubbled inside this flask till hexane had evaporated. This simple procedure proved to be extremely useful to assure low blank absorbance values.

\section{Paraoxonase activity assay}

It was carried out by measuring the p-nitrophenol resulting from serum paraoxon hydrolysis at $\mathrm{pH} 8.5$. The ordinary paraoxonase activity assay was 
performed through mixing the following solutions (always prepared by dissolving every solute into a Tris- $\mathrm{HCl} 0.1 \mathrm{M}$ buffer solution, $\mathrm{pH} 8.5$ ). Firstly, $50 \mu \mathrm{L}$ of serum were pipetted into tubes named "assay". In those "assays" depicted to contain salts, $50 \mu \mathrm{L}$ of a $3 \mathrm{M} \mathrm{NaCl}$ and $12 \mathrm{mM} \mathrm{CaCl}_{2}$ solution were added before adding $150 \mu \mathrm{L}$ of the Tris- $\mathrm{HCl}$ buffer. Into tubes without salts $200 \mu \mathrm{L}$ of the Tris- $\mathrm{HCl}$ buffer alone were added. $50 \mu \mathrm{L}$ of a solution containing $45 \mathrm{mM}$ paraoxon and $45 \%$ DMSO into the Tris- $\mathrm{HCl}$ buffer were pipetted to start the enzymatic reaction. To measure the activity at different $\mathrm{pH}$ values a sodium phosphate buffer $0.1 \mathrm{M}, \mathrm{pH} 6.5$, a Tris-HCl buffer $0.1 \mathrm{M}$, from $\mathrm{pH} 7.0$ up to $\mathrm{pH} 9.0$, and a glycine- $\mathrm{NaOH} 0.1 \mathrm{M}$ buffer, $\mathrm{pH} 9.5$ and $\mathrm{pH} 10.0$, were used to sustain the respective $\mathrm{pH}$ values. To evaluate the influence of different substrate concentrations over the velocity of paraoxon hydrolysis two solutions of paraoxon were used. A $45 \mathrm{mM}$ solution was made by mixing $12 \mathrm{mg}$ of purified paraoxon with $436 \mu \mathrm{L}$ of DMSO and $532 \mu \mathrm{L}$ of Tris- $\mathrm{HCl} 0.1 \mathrm{M}, \mathrm{pH}$ 8.5. A $4.5 \mathrm{mM}$ paraoxon solution was obtained diluting $40 \mu \mathrm{L}$ of the $45 \mathrm{mM}$ solution with $162 \mu \mathrm{L}$ of DMSO and $198 \mu \mathrm{L}$ of Tris- $\mathrm{HCl} 0.1 \mathrm{M}, \mathrm{pH}$ 8.5. Different paraoxon concentrations were used in the range of 0.015 to $7.5 \mathrm{mM}$. To denature the enzymes $0.9 \mathrm{~mL}$ of a $3 \%$ TCA (in water) were pipetted into the tubes once elapsed the appropriated time of each reaction. $50 \mu \mathrm{L}$ of serum were added into the tubes named "blank" (using serum which had been kept along the entire reaction time under the same temperature of the tubes named assay) just after TCA addition. Then, "assay" and "blank" tubes were centrifuged at 4,000 rpm for $15 \mathrm{~min}$ and $0.9 \mathrm{~mL}$ aliquots of each supernatant were mixed with $0.2 \mathrm{~mL}$ of a $0.3 \mathrm{M}$ Tris- $\mathrm{HCl}$ buffer solution, $\mathrm{pH}$ 8.0. Absorbance measurement in each tube was registered at $400 \mathrm{~nm}$ using a Shimadzu UV-160A spectrophotometer in $1 \mathrm{~cm}$ optical path cuvettes. Calculations to know the amount of p-nitrophenol formed was done using a p-nitrophenol standard curve ( 1.5 to 75 nmoles concentration range).

\section{RESULTS}

Paraoxonase activity was not lost during the five days sera were kept in the refrigerator at about $5^{\circ} \mathrm{C}$. Hexane purified paraoxon gave low blank values up to 6 days after being purified. After this time it had to be repurified to be used as substrate of subsequent enzymatic determinations.

As it can be seen in figure 1 it was possible to assay paraoxonase activity of sera from both species of fish for up to 20 min with no significant loss of linearity.

Figure 2 shows that paroxonase activities from serum of pacu and cascudo were proportional to the amount of serum used in the assay. The volume of $50 \mu \mathrm{L}$ of serum we have chosen to assay paraoxonase allowed activities ranging from 3 nmoles of p-nitrophenol $/ \mathrm{min} / \mathrm{mL}$ to $6 \mathrm{nmoles} / \mathrm{min} / \mathrm{mL}$ within $20 \mathrm{~min}$ of incubation. Less than $2 \%$ of paraoxon was utilized over the 20 min assay time at all substrate concentrations by the $50 \mu \mathrm{L}$ of serum.

Inferring from the temperature curves showed in figure 3 the optimum temperature to assay the enzyme activity in our conditions was $30^{\circ} \mathrm{C}$. In figure $3-\mathrm{B}$ it can be seen that cascudo serum paroxonase levels of activity were low in assay tubes without salts, when assays were run at $20^{\circ} \mathrm{C}$ and $15^{\circ} \mathrm{C}$. 

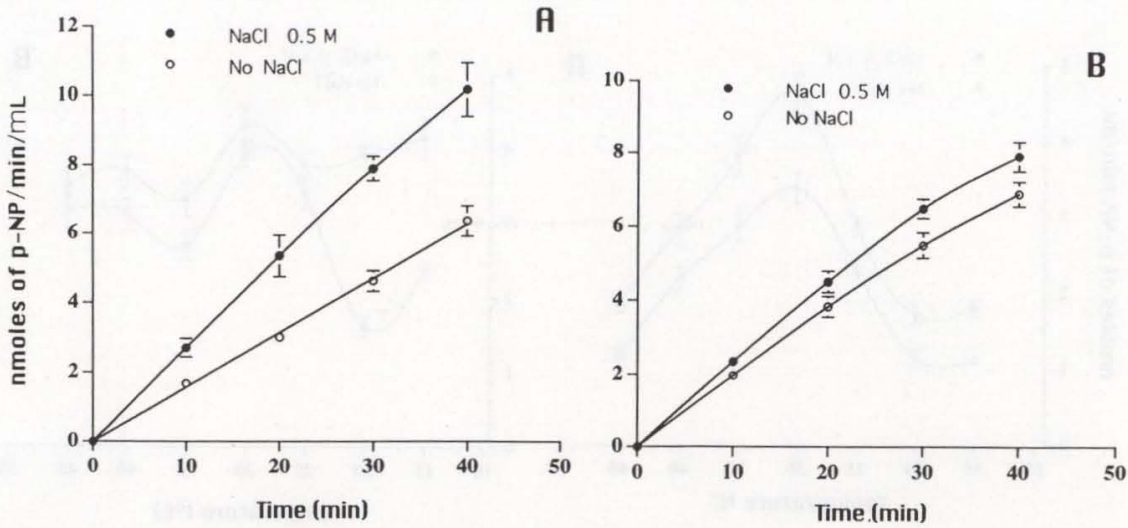

Fig. 1. Paraoxonase serum activity versus incubation time. (A) P. mesopotamicus; (B) $H$. punctatus. Assays were performed at $30^{\circ} \mathrm{C}$, using $0.1 \mathrm{M} \mathrm{Tris-} \mathrm{HCl}$ buffer solution $\mathrm{pH} 8.5,50 \mu \mathrm{L}$ of serum in each tube and $7.5 \mathrm{mM}$ paraoxon. Each point is the mean of six assays \pm S.E.M. Some S.E.M. are too small to be drew to scale and are not shown.
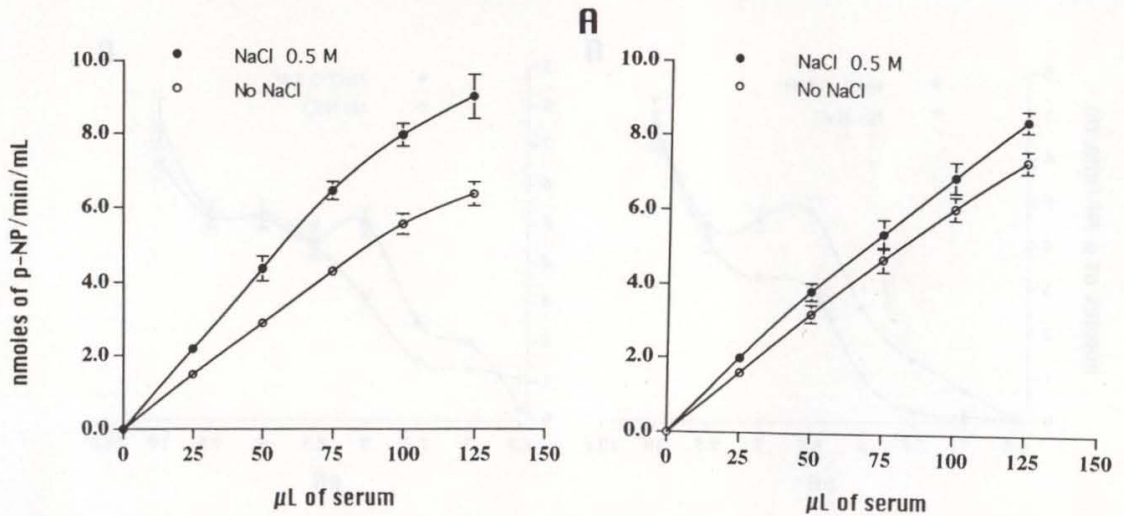

Fig. 2. Paraoxonase activity as a function of serum volume. (A) P. mesopotamicus; (B) $H$. punctatus. Assays were performed at $30^{\circ} \mathrm{C}$ for $20 \mathrm{~min}$, using $0.1 \mathrm{M}$ Tris- $\mathrm{HCl}$ buffer solution $\mathrm{pH}$ 8.5 and $7.5 \mathrm{mM}$ paraoxon. Each point is the mean of 6 assays \pm S.E.M. Some S.E.M. are too small to be drew to scale and are not shown.

As shown in figure 4 serum paraoxonase activity of both fish reached values of activity over $3 \mathrm{nmoles} / \mathrm{min} / \mathrm{mL}$ at $\mathrm{pH} 8.5$. Higher activity levels were found at $\mathrm{pH} 10.0$.

Data presented in figures 1-A, 2-A, 3-A, 4-A show that $0.5 \mathrm{M} \mathrm{NaCl}$ increased the paraoxonase activity of pacu serum. $\mathrm{NaCl}$ at the same concentration had no significative effect over the enzyme activity from cascudo serum assayed at $30^{\circ} \mathrm{C}$ and $\mathrm{pH} 8.5$ (figures 1-B, 2-B, 3-B, 4-B). The double reciprocal plots of $1 / \mathrm{v} \times 1 /[\mathrm{S}]$ (LINEWEAVER \& BURKE 1934) presented in figures 5 and 6 indicate that pacu and cascudo sera were able to hydrolyze paraoxon with maximum velocities $\left(\mathrm{V}_{\max }\right)$ varying from $5.7 \mathrm{nmoles} / \mathrm{min} / \mathrm{mL}$ to $7.9 \mathrm{nmoles} / \mathrm{min} / \mathrm{mL}$. The substrate affinity constants $\left(\mathrm{K}_{\mathrm{M}}\right)$ values presented in figures $5 \mathrm{~A}, \mathrm{~B}$ show that $0.5 \mathrm{M} \mathrm{NaCl}$ provoked a substrate affinity decrease for serum paroxonase activity of pacu serum. Figures 

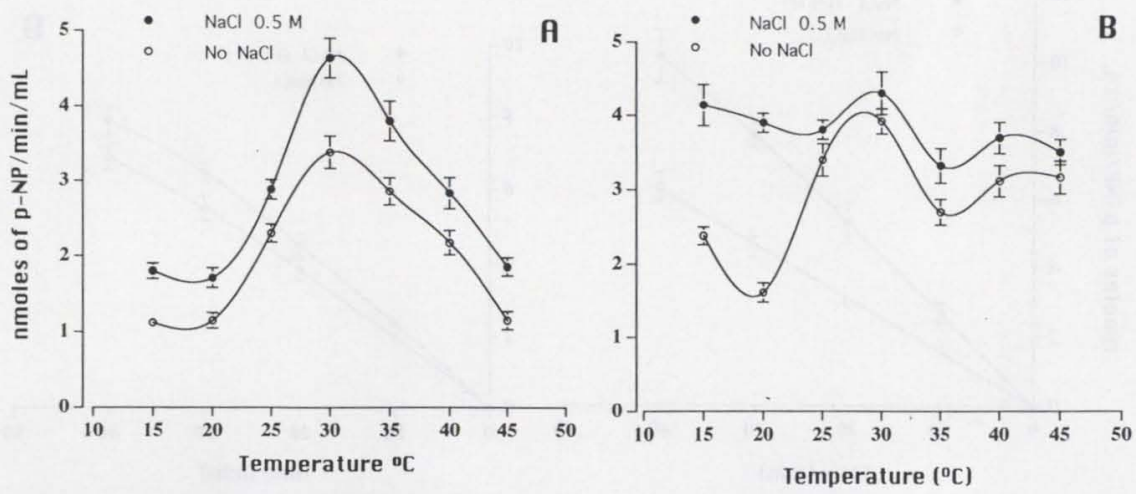

Fig. 3. A typical temperature curve of paraoxonase serum activity. (A) P. mesopotamicus; (B) H. punctatus. Assays were performed for 20 min, using $0.1 \mathrm{M}$ Tris- $\mathrm{HCl}$ buffer solution $\mathrm{pH} 8.5$, $50 \mu \mathrm{L}$ of serum in each tube and $7.5 \mathrm{mM}$ paraoxon. Each point is the mean of 7 assays \pm S.E.M. Some S.E.M. are too small to be drew to scale and are not shown.
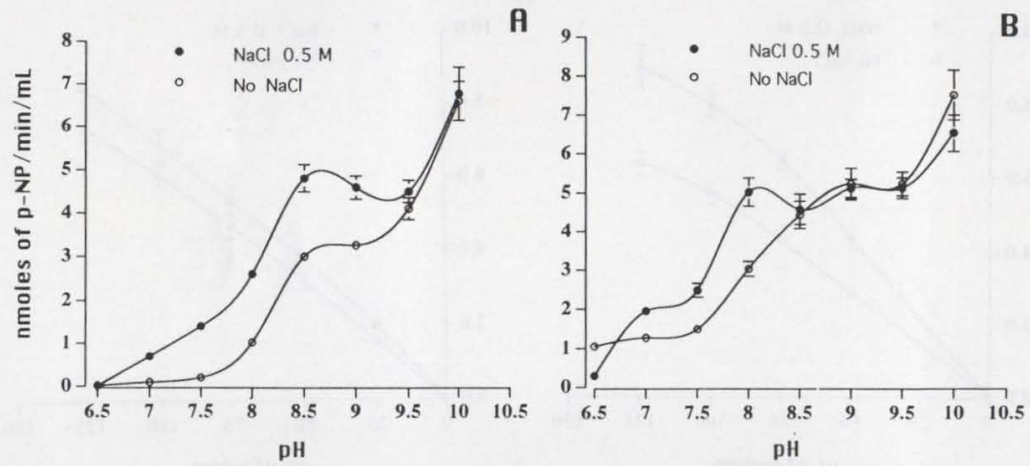

Fig. 4. Influence of pH on enzyme activity. (A) P. mesopotamicus serum. (B) H. punctatus serum. Assays were performed for $20 \mathrm{~min}$ at $30^{\circ} \mathrm{C}$ using $50 \mu \mathrm{L}$ of serum and $7.5 \mathrm{mM}$ paraoxon. Buffers used as described in Material and Methods. Each point is the mean of 5 assays \pm S.E.M. Some S.E.M. are too small to be drew to scale and are not shown.

$6 \mathrm{~A}, \mathrm{~B}$ show that $0.5 \mathrm{M} \mathrm{NaCl}$ was not so effective in diminishing substrate affinity for serum paraoxonase of cascudo. The $\mathrm{K}_{\mathrm{M}}$ values calculated should be taken as minimum values due to the low solubility of paraoxon.

Post-larvae pacu specimens kept in a tank treated with methyl-parathion had their serum paraoxonase activities significantly reduced by $50 \%$ at least (Tab. I). This inhibition was more appreciable when enzyme was assayed in the presence of $0.5 \mathrm{M} \mathrm{NaCl}$.

\section{DISCUSSION}

Measuring serum paraoxonase activity levels to estimate if fish had been exposed to an organophosphate pollutant led us to the need of establishing a validated method of assaying its activity in vitro to avoid misinterpretation of 

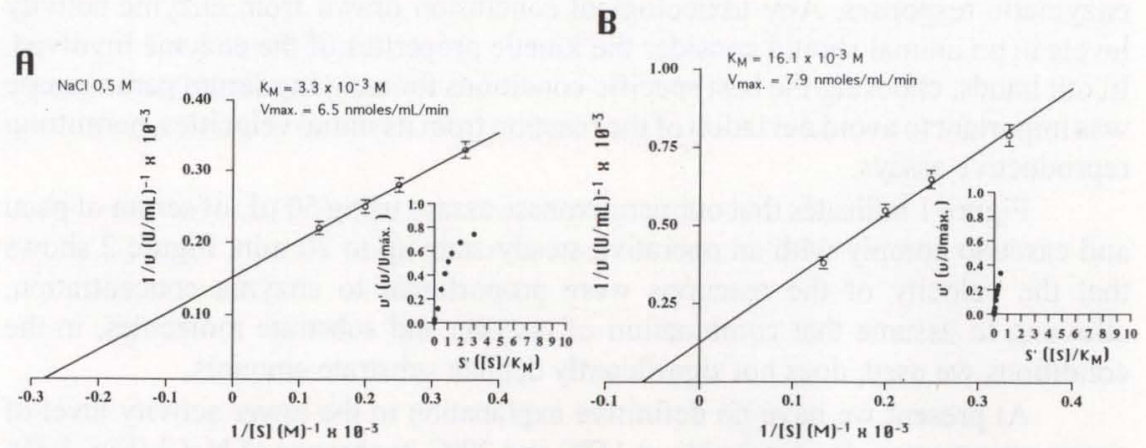

Fig. 5. 1/v versus $1 /[S]$ plot of paraoxonase activity from $P$. mesopotamicus serum. (A) with 0.5 $\mathrm{M} \mathrm{NaCl}$; (B) without $\mathrm{NaCl}$. The inserted v' versus [S]' curves show the relantionship between decimals of $V_{\max }$ and the apparent $\mathrm{K}_{M}$ of the reaction. Each point is the mean of 6 assays \pm S.E.M. Some S.E.M. are too small to be drew to scale and are not shown.
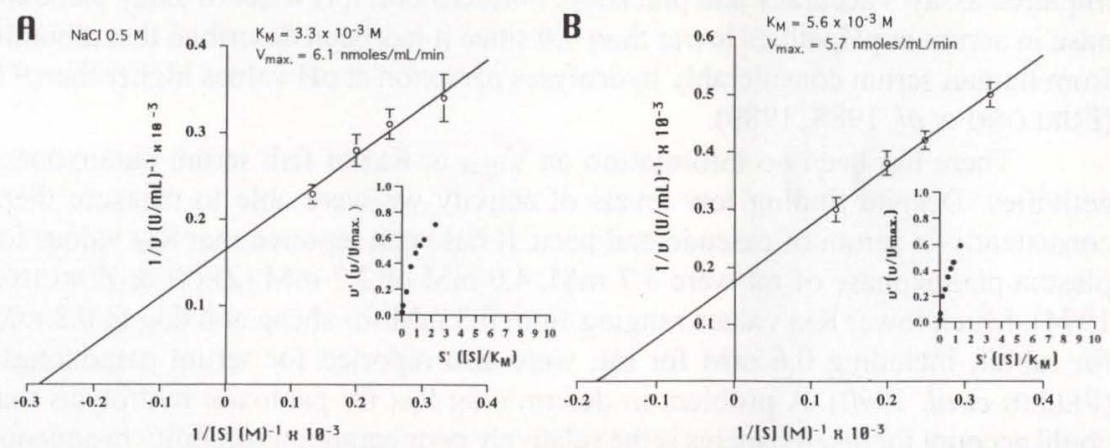

Fig. 6. $1 / \mathrm{v}$ versus $1 /[\mathrm{S}]$ plot of paraoxonase activity from $H$. punctatus serum. (A) with $0.5 \mathrm{M}$ $\mathrm{NaCl}$; (B) without $\mathrm{NaCl}$. The inserted v' versus [S]' curves show the relantionship between decimals of $V_{\max }$ and the apparent $K_{M}$ of the reaction. Each point is the mean of 6 assays \pm S.E.M. Some S.E.M. are too small to be drew to scale and are not shown.

Table I. Serum paraoxonase activity of young $P$. mesopotamicus grown for two months in tanks treated with one $0.25 \mathrm{ppm}$ methyl-parathion dose. Values are expressed as nmoles p-nitro$\mathrm{phenol} / \mathrm{min} / \mathrm{mL}$ of serum.

\begin{tabular}{lll}
\hline & \multicolumn{1}{c}{ Control } & Methyl-parathion \\
\hline $0.5 \mathrm{M} \mathrm{NaCl}$ & $8.79 \pm 1.36(13)$ & $4.82 \pm 1.09(11)^{*}$ \\
Without NaCl & $4.36 \pm 1.54(11)$ & $2.73 \pm 0.81(8)$ * \\
\hline
\end{tabular}

Each value is expressed as the mean \pm the standard deviation. Numbers given between parenthesis indicate how many individual serum samples were assayed. $\left(^{*}\right)$ Student's $t$ test values of $p<0.0001$ and $\left(^{* \star}\right) p<0.04$ related to controls, respectively. 
enzymatic responses. Any toxicological conclusion drawn from enzyme activity levels in an animal should consider the kinetic properties of the enzyme involved. In our hands, choosing the best specific conditions for assaying serum paraoxonase was important to avoid deviation of the reaction from its initial velocities, permitting reproductive assays.

Figure 1 indicates that our paraoxonase assays using $50 \mu \mathrm{L}$ of serum of pacu and cascudo comply with an operative steady-state up to $20 \mathrm{~min}$. Figure 2 shows that the velocity of the reactions were proportional to enzyme concentration, allowing to assume that combination of enzyme and substrate molecules, in the conditions we used, does not significantly deplete substrate amounts.

At present we have no definitive explanation to the lower activity level of serum paraoxonase from cascudo at $15^{\circ} \mathrm{C}$ and $20^{\circ} \mathrm{C}$ in absence of $\mathrm{NaCl}$ (Fig. 3-B). Such a low activity could be explained on the basis of different molecular structural arrangements of the active site on different paraoxonase molecules.

Accordingly the results shown in figure 4 , one could judge more adequate to run paraoxonase assays in serum of both fish at $\mathrm{pH} 10$. However, non-enzymatic hydrolysis of paraoxon is much faster at $\mathrm{pH} 10$ than at $\mathrm{pH}$ 8.5. Consequently, we had frequent high blank values when the activity was assayed at $\mathrm{pH} 10$, what impaired assay's accuracy and precision. Furthermore, it is wiser to assay paraoxonase in serum at $\mathrm{pH}$ values lower than 9.0 since it has been described that albumin from human serum considerably hydrolyses paraoxon at $\mathrm{pH}$ values higher than 9.0 (FURLONG et al. 1988, 1989).

There has been no information on $\mathrm{V}_{\max }$ or $\mathrm{K}_{\mathrm{M}}$ of fish serum paraoxonase activities. Despite finding low levels of activity we were able to measure them consistently in serum of cascudo and pacu. It has been reported that $\mathrm{K}_{\mathrm{M}}$ values for plasma paraoxonase of rat were $3.7 \mathrm{mM}, 4.0 \mathrm{mM}$ or $2.7 \mathrm{mM}$ (ZECH \& ZÜRCHER 1974). Much lower $K_{M}$ values ranging from $0.3 \mathrm{mM}$ for sheep and dog to $0.8 \mathrm{mM}$ for rabbit, including $0.6 \mathrm{mM}$ for rat, were also reported for serum paraoxonase (PELLIN et al. 1990). A problem in determining $\mathrm{K}_{\mathrm{M}}$ for paraoxon hydrolysis that could account for discrepancies is the relatively poor paraoxon solubility in aqueous buffer solutions. If paraoxon molecules are not available to the active site of the enzyme in the incubaton mixtures a "plateau" of a hyperbolic plot could indicate a false approximation to a maximum velocity reached at non-saturating paraoxon (insoluble) concentrations. This would lead one to calculate a low $\mathrm{K}_{\mathrm{M}}$ assuming an apparent saturation of the enzyme. Using 7.5\% DMSO in the incubation media allowed paraoxon concentrations up to $7.5 \mathrm{mM}$ in our assays with less than $5 \%$ of paraoxonase inhibition. Observing the inserted v' (v/V $\left./ \mathrm{V}_{\max }\right)$ versus S' $\left([\mathrm{S}] / \mathrm{K}_{\mathrm{M}}\right)$ plots in figures 5 and 6 it is noteworthy that $7.5 \mathrm{mM}$ paraoxon did not correspond to 10 -fold $\mathrm{K}_{\mathrm{M}}$, which would be the adequate kinetic substrate concentration to ensure the experimental maximum velocity. Nonetheless, $7.5 \mathrm{mM}$ paraoxon caused paraoxonase activity to reach more than $60 \%$ of $\mathrm{V}_{\max }$ in sera of both fish species (Figs 5-A and 6-A, inserts). This made feasible to choose the practical $25 \%$ to $70 \% \mathrm{~V}_{\max }$ best points of observed velocities related to the experimental substrate concentrations for graphing weighed $1 / \mathrm{v}$ versus $1 /[\mathrm{S}]$ plots that allowed acceptable approximations for $\mathrm{K}_{M}$ calculation. Therefore, the higher apparent $\mathrm{K}_{M}$ value of $3.3 \mathrm{mM}$ we 
found for serum paraoxonase of pacu and cascudo, in the presence of $0.5 \mathrm{M} \mathrm{NaCl}$, agreed with those calculated for rat (ZECH \& ZÜRCHER 1974).

Comparison of $\mathrm{V}_{\max } / \mathrm{K}_{\mathrm{M}}$ ratio values of determinations in the presence $\left(1.97 \times 10^{-3} \mathrm{~min}^{-1}\right.$ for pacu and $1.85 \times 10^{-3} \mathrm{~min}^{-1}$ for cascudo $)$ and absence $(0.49 \mathrm{x}$ $10^{-3} \mathrm{~min}^{-1}$ for pacu and $1.02 \times 10^{-3} \mathrm{~min}^{-1}$ for cascudo) of $0.5 \mathrm{M} \mathrm{NaCl}$ in the assays showed that $\mathrm{NaCl}$ had an effect on the affinity of serum paraoxonase for paraoxon in both fish species. These numbers show that paraoxonase of pacu serum was twice more activated than cascudo's activity. Assays of serum paraoxonase activity from individuals are being runned to establish if such a $\mathrm{NaCl}$ effect could be concerned with fenotypical differences as described before for human beings (ECKERSON et al. 1983).

It was relevant to see that the paraoxonase serum activity we managed to measure changed by keeping fish in a tank with methyl-parathion (Tab. I). At present, there is no detailed explanation for the observed inhibition. In spite of the high $\mathrm{K}_{\mathrm{M}}$ observed in pacu and cascudo serum for paraoxon hydrolysis, which must cause the reaction to be operating in vivo at a small fraction of the maximum rate, it might be important to investigate if such an inhibition can be useful as a possible sensitive bioindicator capable of informing that fish had been in contact with an amount of organophosphorous pesticide. One can only hypothesize that the protein responsible for paraoxonase fish serum activity would, as several other serum proteins, be produced in liver and that methyl-parathion could be affecting the hepatic synthesis or exportation of paraoxonase in young pacus. Studies on liver and serum paraoxonase activities in intoxicated young pacus specimens are now under way in our laboratory to establish which enzyme activity is more important to sublethal intoxication in pacu. Considering the high enzymatic activity levels observed when sera of non-intoxicated young individuals were assayed in the presence of $0.5 \mathrm{M} \mathrm{NaCl}$ we will be also performing assays to learn whether paraoxonase activity is higher in very young fish than in adult ones.

ACKNOWLEDGEMENTS. The authors are grateful to the support provided by the Rio de Janeiro State Research Support Foundation (FAPERJ).

\section{REFERENCES}

ALDRIDGE, W.N. 1953. Serum esterase 2: an enzyme hydrolyzing diethyl p-nitrophenyl phosphate (E600) and its identity with the A-esterase of mammalian sera. Biochem. Jour. 53: 117-124.

BenKe, G.M.; K.L. CheEver; F.E. Mirer \& S.D. MurPhy. 1974. Comparative toxicity, anticholinesterase action and metabolism of methyl parathion and parathion in sunfish and mice. Toxicol. Appl. Pharmacol. 28: 97-109.

BRIMBLECOMBE, R.W. 1977. Drugs acting on central cholinergic mechanisms and affecting respiration. Pharcol. Ther. 3: 65-74.

Brealey, C.J.; C.H. WALKer \& B.C. BaldWIN. 1980. A-esterase activities in relation to the differential toxicity of pirimiphos-methyl to birds and mammals. Pestic. Sci. 11: 546-554. 
ChemNitius, J-M.; H. LosCH; K. LosCH \& R. ZECH. 1983. Organophosphate detoxicating hydrolases in different vertebrate species. Comp. Biochem. Physiol. 76C: 85-93.

Cunha Bastos, J.; V.L.F. Cunha Bastos; A. Rossini; H. Fortini \& M.V. CASTRO FARIA. 1992. Activation of parathion by liver of Hypostomus punctatus, a Brazilian benthic fish (Cascudo). Comp. Biochem. Physiol. 94C: 683-689.

Cunha Bastos, V.L.F.; J. Cunha Bastos; R.L. Mendonça \& M.V. Castro FARIA. 1988. Main kinetic characteristics of acetylcholinesterase from brain of Hypostomus punctatus, a Brazilian bentonic fish (cascudo). Comp. Biochem. Physiol. 91C: 327-331.

Diggle, W.M. \& J.C. GAGE. 1951. Cholinesterase Inhibition in vitro by OO-Diethyl O-p-nitrophenyl Thiophosphate (Parathion, E 605). Biochem. Jour. 49: 491-494.

DuBoIs, K.P. 1961. Potentiation of the toxicity of organophosphorus compounds. Adv. Pest Control Res. 4: 117-151.

ECKeRson, H.W.; J. RoMson; C. Wyte \& B. LA Du. 1983. The human serum paraoxonase polymorphism: Identification of phenotypes by their response to salts. Amer. Jour. Hum. Genet. 35: 214-227.

ECOBICHON, D.J. 1996. Toxic effects of pesticides, p.643-689. In: C.D. KLAASSEN (Ed.). Casarett and Doul's Toxicology - The Basic Science of Poisons. New York, MacGraw-Hill Co. Inc., $5^{\text {th }}$ ed, 1111 p.

FuRLONG, C.E.; R.J. RichteR; S.L. SEIDEL \& A.G. MotUlsKy. 1988. Role of genetic polymorphism of human plasma paraoxonase/ arylesterase in hydrolysis of the insecticide metabolites chlorpyrifos oxon and paraoxon. Amer. Jour. Hum. Genet. 43: 230-238.

FURLONG, C.E.; R.J. RICHTER; S.L. SEIDEL; L.G. COSTA \& A.G. MOTULSKY. 1989. Spectrophotometric assays for the enzymatic hydrolysis of the active metabolites of chlorpyrifos and parathion by plasma paraoxonase/arylesterase. Anal. Biochem. 180: 242-247.

GRAVE, K.; M. ENGLESTAD \& N.E. Soli. 1991a. Utilization of dichlorvos and trichlorfon in salmonid farming in Norway during 1981-1988. Acta Vet. Scand. 32: 1-7.

Grave, K.; M. Englestad; N. E. Soli \& E. L. Toverud. 199lb. Clinical use of dichlorvos (Nuvan) and Trichlorfon (Neguvon) in the treatment of salmon louse, Lepeophtheirus salmonis. Compliance with the recommended treatment procedures. Acta Vet. Scand. 32: 9-14.

LI, W.F.; C.E. FuRLONG \& L.G. CosTA. 1993. Serum paraoxonase status: a major factor in determining resistance to organophosphates. Jour. Toxicol. Environ. Health 40: 337-346.

1995. Paraoxonase protects against chlorpyrifos toxicity in mice. Toxicol. Letters, 76: 219-226.

LINEWEAVER, H. \& D. BURKE. 1934. The determination of enzyme dissociation constants. Jour. Amer. Chem. Soc. 56: 658-666.

MAIN, A.R. 1976. Structure and inhibitors of cholinesterase, p.269-353. In: M. GoldBERG \& I. HANIN (Ed.). Biology of Cholinergic Function. New York, Raven Press, 512p. 
MuRPHy, S.D. 1975. Pesticides, p.408-453. In: L.J. CASARETT \& J. Doull (Ed.). Toxicology the Basic Science of Poinsons. New York, Macmillan Publishing Co. Inc, $768 \mathrm{p}$.

NAtoff, I.L. 1971. Organophosphorus pesticides. Pharmacol. Prog. Med. Chem. 8: 1-37.

NEAL, R.A. 1967. Studies on the metabolism of diethyl 4-nitrophenyl phosphorothionate (parathion) in vitro. Biochem. Jour. 103: 183-191.

NEAL, R.A. \& K.P. DUBoIs. 1965. Studies on the mechanism of detoxification of cholinergic phosphorothioates. Jour. Pharmacol. Exp. Therapeut. 148 (2): 185-192.

Pellin, M.C.; A. MoretTo; M. LotTi \& E. Vilanova. 1990. Distribution and some biochemical properties of rat paraoxonase activity. Neurotoxicol. Teratol. 12: 611-614.

PlAYFER, J.R.; L.C. EzE; M.F. BULLEN \& D.A.P. EVANS. 1976. Genetic polymorphism and interethnic variability of plasma paroxonase activity. Jour. Med. Genet. 13: 337-342.

REINER, E.; M.K. JOHNSON \& M. JOKANOVIC. 1993. Hydrolysis of some organophosphorus dichlorophenyl esters by hen brain homogenates and rabbit serum compared with hydrolysis of paraoxon. Chem. Biol. Interactions 87: 127-131.

WALKER, C.H. 1993. The classification of esterases which hydrolyse organophosphates: recent developments. Chem. Biol. Interactions 87: 17-24.

WALKER, C.H. \& M.I. MACKNESS. 1987. A-esterases and their role in regulating the toxicity of organophosphates. Arch. Toxicol. 60: 30-33.

ZECH, R. \& K. ZÜRCHER. 1974. Organophosphate splitting serum enzymes in different mammals. Comp. Biochem. Physiol. 48B: 427-433.

Recebido em 28.II.1997; aceito em 03.VIII.1998. 